Tecno Lógicas

ISSN 0123-7799

Vol. 19, No. 37, pp. 93-106

Julio-diciembre de 2016

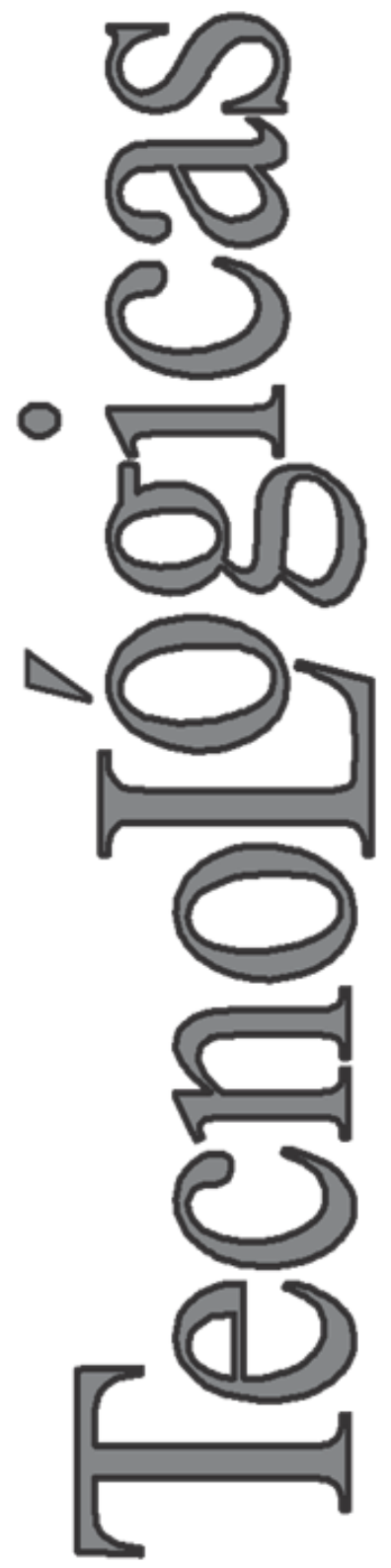

(C) Copyright 2015 por Autores y Tecno Lógicas Este trabajo está licenciado bajo una Licencia Internacional Creative Commons Atribución (CC BY)

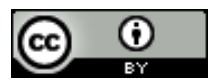

\section{Impact of government incentives in the profitability of green energy production using fuel cells in Colombia}

\section{Impacto de los incentivos del gobierno en la rentabilidad de la producción de energía renovable mediante celdas de combustible en Colombia}

\author{
Bernardo A. Potosí-Guerrero ${ }^{1}$, \\ Carlos A. Ramos-Paja ${ }^{2}$, y Sergio I. Serna-Garcés ${ }^{3}$
}

Recibido: 19 de febrero de 2016,

Aceptado: 23 de junio de 2016

Cómo citar / How to cite

B.A. Potosí-Guerrero, C.A. Ramos-Paja y S.I. Serna-Garcés "Impact of government incentives in the profitability of green energy production using fuel cells in Colombia”, Tecno Lógicas, vol. 19, no. 37, pp.93-106, 2016.

1 Ingeniero de Control, Joven Investigador Colciencias, Departamento de Energía Eléctrica y Automática, Universidad Nacional de Colombia, Medellín-Colombia, bapotosig@unal.edu.co

2 Ph.D. en Ingeniería Electrónica, Automática y Comunicaciones, Profesor Asociado, Departamento de Energía Eléctrica y Automática, Universidad Nacional de Colombia, Medellín-Colombia, caramosp@unal.edu.co

3 M.Sc. en Ingeniería - Ingeniería de Sistemas, Profesor Auxiliar, Departamento de Electrónica y Telecomunicaciones, Instituto Tecnológico Metropolitano, Medellín-Colombia, sergioserna@itm.edu.co 


\section{Abstract}

Fuel cells are a technological alternative to produce green energy, however, high costs make fuel cell a non-profitable option. This paper analyses the impact of the Colombian government incentives in the profitability of fuel cells. The analysis is based on the total operation cost of the fuel cell in three representative applications: residential, office and building elevator. The economic viability of fuel cell generation in those cases is contrasted with classical solutions like diesel generators and standard grid to provide a reference framework. Such results enable to evaluate the effectiveness of the Colombian government incentives in promoting the use of fuel cells over other less environmental-friendly options such as diesel generators. Finally, new incentives are proposed by subsidies offered by other countries with higher fuel cell penetration into their electric market. All the analyses are supported in simulations performed with a mathematical model parameterized using the characteristics of commercial devices.

\section{Keywords}

Fuel cells, green government, electricity production, tax incentives, government subsidies.

\section{Resumen}

Las celdas de combustible son alternativas tecnológicas para producir energía renovable, sin embargo, los altos costos hacen a estas una opción poco rentable. Este artículo analiza el impacto de los incentivos del Gobierno de Colombia en la rentabilidad de la generación de energía eléctrica a partir de celdas de combustible. El análisis está basado en los costos totales de la operación de las celdas de combustible en tres escenarios representativos: una residencia, una oficina y un elevador de un edificio. La viabilidad económica de la generación con celdas de combustible en estos tres casos es contrastada con soluciones clásicas como generación a partir de diésel y la red eléctrica convencional. Los resultados permiten identificar que los incentivos del Gobierno de Colombia son muy efectivos para quienes generen a partir de energía renovable, como celdas de combustible, en contraste con otras opciones menos amigables con el medio ambiente, como los generadores diésel. Finalmente, nuevos incentivos son propuestos sobre la base de subsidios ofrecidos por otros países con alta penetración de las celdas de combustible en su mercado eléctrico. Todos los análisis están soportados en simulaciones realizadas con modelos matemáticos parametrizados que consideran las características de los dispositivos comerciales.

\section{Palabras clave}

Celdas de combustible, Gobierno verde, generación eléctrica, incentivos fiscales, subsidios del gobierno. 


\section{INTRODUCTION}

Fuel cells are emerging as an alternative for clean electricity generation, i.e. green power sources. Fuel cells are environmentally friendly power sources due to its free of noise operation, high efficiency and almost free of pollutants residuals. Such characteristics make fuel cells a suitable option to replace classical generators based on internal combustion engines, which are noisy, pollutant and require frequent maintenance due to their large number of mobile parts [1].

Moreover, fuel cells are predictable green power sources, which is a major advantage over unpredictable renewable generators such as photovoltaic systems (PV) or wind generators (WG) [2]. The power production predictability enables to design, precisely, the power flows in the fuel cell system without the uncertainty caused by, for example, clouding or low wind speed present in PV or WG systems. Moreover, the local area required to install a fuel cell generator is significantly lower in comparison with other green power sources such as PV or WG systems. For example, at Hartford Hospital in Hartford (Connecticut, USA), the installation of a 1.4 MW fuel cell system required 209.02 $\mathrm{m} 2$, while a solar array with the same power will require 200 times more area as reported in [3]. Similarly, a 14.9 MW fuel cell system installed at a Dominion facility in Bridgeport (Connecticut, USA) required $6,070 \mathrm{~m} 2$ as reported in [3]. In contrast, a wind turbine of $2.5 \mathrm{MW}$ requires 242,811 $\mathrm{m} 2$ per MW [4]. Hence it is required near to $3640000 \mathrm{~m} 2$ with six wind turbines to generate the same capacity.

Despite those benefits, the main disadvantage of fuel cells is its high cost, which prevents its integration in the energy basket of some countries.

However, countries like Germany, USA, Japan, Australia and Brazil, among others, are part of the International Partnership for Hydrogen and Fuel Cells in the Econo- my (IPHE) created in 2003. The IPHE is aimed at accelerating the transition to a hydrogen economy, promoting their income and commercialization in the energy market through economic incentives and government policies, those with the aim of reducing the fuel cell costs and increase their competitiveness within the market [5].

In Latin America, Argentina approved in 2006 the "Hydrogen Act" (Act 26,123), which defined "Of national interest the development of hydrogen technology as fuel and energy sector" [6]. This political will contribute at promoting the development and investment in fuel cells. However, delays in the Act regulation have compromised its effectiveness [7].

Similarly, Colombia approved the Act 1715 in 2014, which regulates the integration of non-conventional renewable energy into the national power grid. This Act establishes incentives to non-conventional renewable energy. Moreover, the current Tax Statute in Colombia provides an additional incentive to legal persons (any company or organization with investment capacity): the investments in environmental improvement are suitable for a tax deduction of $100 \%$ of the investment.

Using the previous legal conditions, the profitability of fuel cell generation in Colombia is studied in this paper for three representative cases: residential, office and building elevators. The objective of this study is to analyze the viability of fuel cells as an economical alternative in two applications: first, as a backup generator in urban areas; and second, as the main generator in off-grid zones, which represents near $50 \%$ of the Colombian territory. In both applications, the main objective is to replace the large amount of diesel generators, which are pollutant and noisy devices.

The study is performed by comparing the purchasing, taxes, and operation costs of fuel cells and diesel generators using standard load profiles. Moreover, the cost of supplying the load profiles using the 
conventional power grid is also calculated to provide a reference framework. On the basis of the study results, the possible advantages in fuel cell investments in Colombia are discussed and remarked. In addition, the Colombian incentives are compared with incentives provided by other countries, which enable to propose a new government incentive to cover some cases that are out of the scope in the current Colombian legislation. Such, a new incentive will be aimed at promoting the use of fuel cells in residences, which will be very beneficial for non-interconnected zones.

The paper is organized as follows: Section 2 introduces three study cases, for which the operational costs of fuel cell power systems are calculated. Section 3 calculates the operational costs of classical generation solutions for the same applications cases, which enable to evaluate the profitability of fuel cell systems. Then, Section 4 analyzes the impact of the economic incentives provided by the Colombian government aimed at promoting the use of fuel cells. Section 5 analyzes the economic incentives provided by other countries to propose new incentives for the Colombian market. Finally, the conclusions close the paper.

\section{CALCULATION OF FUEL CELL OPERATION COSTS}

A complete analysis of return on investment should include: system size, productivity improvements, system cost, system lifetime, fuel cost and tax credit.

Productivity improvements are related with to suspend the service due to refueling. This impact depends on the daytime when refueling is performed. A cost very hard of to estimate, so that it was not considered.

The first step in the economic analysis is to calculate the operational costs of commercial fuel cells in the application cases, which includes the purchasing, importing, depreciating and hydrogen consumption costs. The residential and office applications were chosen because they conform a large sector of low power rating in Colombia, which uses diesel generators as backup sources. Similarly, a lot of building elevators (in both residential and commercial sectors) use diesel generators as backup sources.

The following subsections illustrate how the hydrogen consumption of commercial fuel cells was calculated for the three application cases. The cost of that hydrogen mass is estimated based on commercial prices in Colombia. Due to the immature technology, the cost of the fuel has large fluctuation, since the costs associated with production, distribution, storage and infrastructure are unknown. Subsequently, the purchasing, importing and depreciating costs are estimated to provide a unified monthly cost.

\subsection{Hydrogen consumption costs}

The commercial fuel cell for each application was selected from the maximum power reported in each load profile. Then, the mathematical fuel cell model reported in [8] was parameterized in agreement with the characteristic of each commercial device.

Those models were used to simulate the operation of each application during 24 hours to calculate the amount of hydrogen consumed. To match the voltage levels between the output of the fuel cells and the load, a DC/DC power boost converter was included in the simulation to provide a realistic power stage. In this fuel cell system, the main power losses are generated by the power stage, it reaching efficiencies of $86.6 \%, 89.5 \%$ and $77.2 \%$ for residential, office and building elevator application, respectively. The efficiency of commercial inverters is very high, near to $97 \%$ as reported in [9]. 
Fig. 1 shows the daily load profiles for the three study cases. Similarly, Table 1 presents the technical specifications of the commercial fuel cells selected for those applications cases: E-2500 for the residential case, FCS-C3000 for the office case and HyPMTMHD 30 for the building elevators case. The lifetime stack parameter indicates the replace time of the Proton Exchange Membrane -- PEM. But the complete system is formed by the controller, power conditioning, fuel supply, power supply, measurement equipment, and others. Changing the PEM every two or three years, the complete system has a lifetime of ten years approximately. Nevertheless, for the analysis performed we consider only the stack lifetime. Finally, the block diagram of the simulation scheme, implemented in Simulink/Matlab, is presented in Fig. 2.

Table 2 reports the hydrogen consumption results obtained by the simulations for 24 hours. Moreover, Table 2 also includes the commercial cost of the hydrogen (Type 5) in Colombia, for calculating the consumption costs. Finally, Table 2 also reports the consumption costs for both daily and monthly periods.

The average monthly cost of the fuel was calculated on the base of 365 days of operation a year. Nevertheless, the office certainly does not operate on weekends or holiday periods, the house probably has an occupancy close to 365 days a year, while the elevator depends on the type of building, whether it is commercial or residential. a)

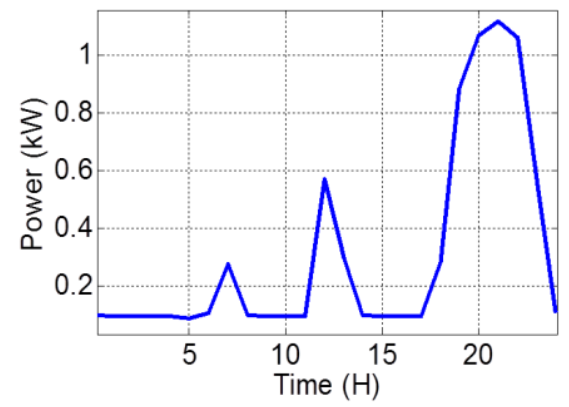

b)

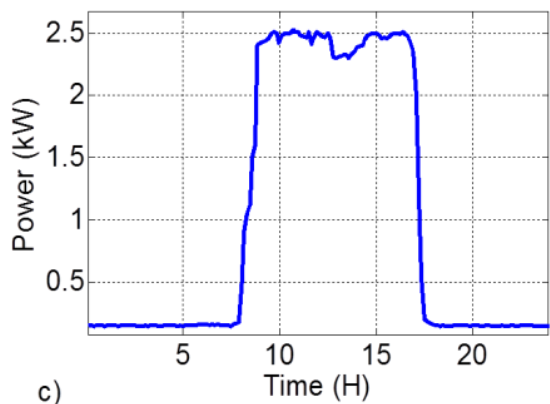

c)

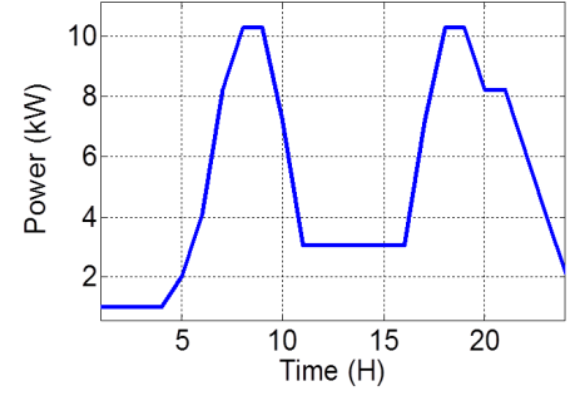

Fig. 1. Load profiles for the application cases: a) Residential [10], b) Office, c) Building elevator [11]. Source: authors.

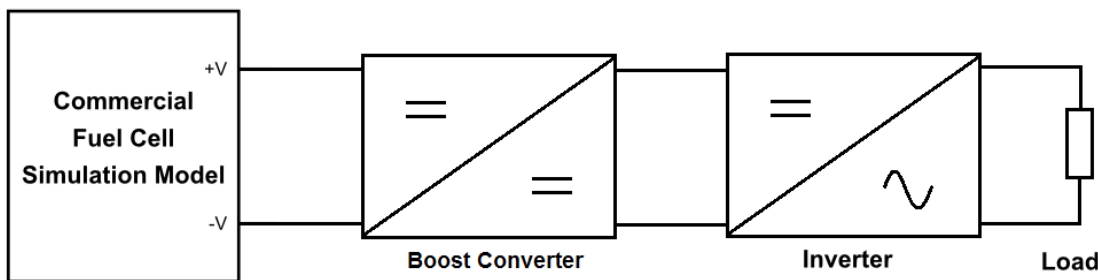

Fig. 2. Simulation scheme to calculate the hydrogen consumption. Source: authors. 


\subsection{Purchasing, importing and depreciating costs}

To estimate the complete costs of a fuel cell application, the purchasing, importing and depreciating costs must be included. The purchasing [12]-[14] and importing costs [15], [16] were obtained from both manufacturers and a local logistic agent, respectively. The total cost of purchasing and importing were calculated as reported in Eq. (1),

$\mathrm{P} \& \mathrm{I}=(\mathrm{FCC} *(1+\mathrm{T})) *(1+\mathrm{VAT})+\mathrm{TLE}+\mathrm{CF}+\mathrm{LF}$

where FCC represents the fuel cell, transportation, and insurance costs; $\mathrm{T}$ represents the import tariff in Colombia ( $5 \%$ for this kind of equipment); VAT is the added value tax in Colombia (16\%), TLE and $\mathrm{CF}$ are the port and forms costs, and
LF represents the transportation costs within Colombia [17], [18]. TLE costs are related to releasing the fuel cell in the airport, while CF corresponds to customs commissions, licenses, forms, declarations, tariff position and warehousing. The additional cost over the price of the fuel cell is approximately $33 \%$.

The depreciating costs were calculated as in Eq. (2) using the fuel cell lifetimes presented in the Table 1 . Nevertheless, to get closer to reality, the fuel cell system lifetime should be very much greater. The results are presented in the Table 3 , which corresponds to a continuous operation during 24 hours and 30 days. The last column of Table 3 reports the equivalent monthly cost of the fuel cells.

$$
\begin{gathered}
\text { Fuel Cell } \\
\text { Montly depreciation }
\end{gathered}=\frac{\text { Total } \text { cost }}{\text { Lifetime }} * 24 * 30
$$

Table 1: Commercial fuel cells used in the three applications. Source: authors.

\begin{tabular}{|c|c|c|}
\hline Manufacturer & Reference & Technical Specifications \\
\hline \multirow{5}{*}{ ReliOn } & \multirow{5}{*}{$\mathrm{E}-2500$} & Power: $2.5 \mathrm{~kW}$ \\
\hline & & Current: 52.5 A@ @ 48 VC \\
\hline & & Voltage: $48 \mathrm{~V}_{\mathrm{DC}}$ \\
\hline & & Efficiency: $40 \%$ \\
\hline & & Stack lifetime: 6000 h approx. \\
\hline \multirow{5}{*}{ Horizon } & \multirow{5}{*}{ FCS-C3000 } & Power: $3 \mathrm{~kW}$ \\
\hline & & Current: $70 \mathrm{~A}$ \\
\hline & & Voltage: $43.2 \mathrm{~V}_{\mathrm{DC}}$ \\
\hline & & Efficiency:40\%@43.2 A \\
\hline & & Stack lifetime: $4000 \mathrm{~h}$ approx. \\
\hline \multirow{5}{*}{ Hydrogenics } & \multirow{5}{*}{ HyPM $^{\text {тм}}{ }^{2} 30$} & Power: $33 \mathrm{~kW}$ \\
\hline & & Current: 0-500 A \\
\hline & & Voltage: $60-120 \mathrm{~V}_{\mathrm{DC}}$ \\
\hline & & Efficiency: $55 \%$ \\
\hline & & Stack lifetime: $10000 \mathrm{~h}$ approx. \\
\hline
\end{tabular}

Table 2: Hydrogen consumption costs. Source: authors.

\begin{tabular}{lcccc}
\hline Application & $\begin{array}{c}\text { Consumed Amount } \\
\text { in } 24 \mathrm{H} .(\mathrm{kg})\end{array}$ & $\begin{array}{c}\mathrm{H}_{2} \text { Cost per } \\
\text { kg US } \$\end{array}$ & $\begin{array}{c}\text { Cost of } 24 \text { hours of } \\
\text { Operation US } \$\end{array}$ & $\begin{array}{c}\mathrm{H}_{2} \text { Monthly con- } \\
\text { sumption cost US } \$\end{array}$ \\
\hline Residential & 0.344 & 1.51 & 0.52 & 15.6 \\
Office & 1.23 & 1.51 & 1.86 & 55.7 \\
B. Elevator & 7.85 & 1.51 & 11.85 & 355.6 \\
\hline
\end{tabular}


Impact of government incentives in the profitability of green energy production using fuel cells in Colombia

Table 3: Total costs in Colombia of fuel cells after purchasing and importing. Source: authors.

\begin{tabular}{cccc}
\hline Manufacturer & Power $(\mathrm{kW})$ & $\begin{array}{c}\text { Total Cost of } \\
\text { P\&I US } \$\end{array}$ & $\begin{array}{c}\text { Fuel Cell monthly } \\
\text { depreciation US } \$\end{array}$ \\
\hline ReliOn & 2.5 & 12,185 & $1,462.20$ \\
Horizon & 3.0 & 14,906 & $2,683.08$ \\
Hydrogenics & 33 & 26,417 & $1,902.02$
\end{tabular}

\subsection{Total operation costs}

Combining the monthly hydrogen consumption presented in Table 2 and the fuel cells monthly depreciation given in Table 3, the total operation costs of the fuel cells are reported in Table 4.

\begin{tabular}{lc}
\multicolumn{2}{c}{ Table 4: Total operation costs of fuel cells. Source: authors. } \\
\hline Application & Total Monthly Operational costs \\
& US $\$$ \\
\hline Residential & $1,477.80$ \\
Office & $2,738.78$ \\
B. Elevator & $2,257.62$ \\
\hline
\end{tabular}

\section{COMPARISON WITH CONVENTIONAL POWER SOURCES}

The following subsections describe the calculation of the operational costs in $\mathrm{Co}^{-}$ lombia for diesel generators and conventional grid in the three study cases.

\subsection{Operational costs of conventional sources}

\subsubsection{Diesel Generators.}

In order to obtain the equivalent monthly operational costs, the price of suitable diesel generators for each application was obtained from local providers. Then, according to the fuel consumption, the fuel cost, the generator lifetime and the estimated installation and maintenance costs of the generator, the operational costs were calculated. Eq. (3) reports the calculation of the monthly depreciation of the diesel generators, adding their estimated monthly maintenance. Similarly, Eq. (4) shows the calculation of the cost of the fuel consumed by each diesel generator. Table 5 and Table 6 report the calculation results.

The total monthly operational costs of diesel generators corresponds to the sum of the monthly depreciation and maintenance costs reported in Table 5 and the monthly fuel cost reported in Table 6 .

\subsubsection{Conventional Power Grid.}

The equivalent monthly cost of this energy source was calculated from Eq. (5), using the energy calculated by the simulation of the three load profiles. Moreover, the grid energy cost per $\mathrm{kWh}$ was taken from the local provider in Medellín - $\mathrm{Co}^{-}$ lombia. Those costs per $\mathrm{kWh}$ were differentiated between residential and nonresidential customers, which include the lifetime that, for hydroelectric generation, is 50 to 100 years [19], [20]. Therefore, the office and building elevator applications were classified within the non-residential rate. Table 7 reports obtained results.

$$
\begin{aligned}
& \begin{array}{l}
\text { D. G. monthly deprec. } \\
\text { and maintenance }
\end{array}=\frac{\text { Equipment cost }}{\text { Lifetime }} * \frac{1}{12}+\begin{array}{c}
\text { Estimated } \\
\text { maintenance }
\end{array} \\
& \begin{array}{l}
\text { Monthly } \\
\text { Fuel cost }
\end{array}=\underset{\text { Consumed }}{\text { Fuel }}\left(\frac{\ell}{\text { hour }}\right) * \underset{\text { cost }}{\text { Fuel }}\left(\frac{\text { US } \$}{\ell}\right) * 24 * 30 \\
& \begin{array}{l}
\text { Convent. Power Grid } \\
\text { Montly usage cost }
\end{array}=k W h \text { consumed } * \frac{U S \$}{k W h} * 30
\end{aligned}
$$


Impact of government incentives in the profitability of green energy production using fuel cells in Colombia

Table 5. Diesel generators equivalent operational costs. Source: authors.

\begin{tabular}{lccccc}
\hline Application & $\begin{array}{c}\text { Generat. } \\
\text { Power (kW) }\end{array}$ & $\begin{array}{c}\text { Life-Time } \\
\text { (Years) }\end{array}$ & $\begin{array}{c}\text { Equipment } \\
\text { cost US\$ }\end{array}$ & $\begin{array}{c}\text { Estimated Monthly } \\
\text { Maintenance US\$ }\end{array}$ & $\begin{array}{c}\text { Monthly deprec. } \\
\text { with maintenance } \\
\text { US\$ }\end{array}$ \\
\hline Residential & 2.5 & 5 & 369.71 & 8.47 & 14.60 \\
Office & 3.1 & 5 & 429.04 & 8.47 & 15.60 \\
B. Elevator & 25 & 10 & 10887.43 & 33.9 & 124.63 \\
\hline
\end{tabular}

Table 6: Diesel generators monthly fuel costs. Source: authors.

\begin{tabular}{lcccc}
\hline Application & $\begin{array}{c}\text { Generator Power } \\
(\mathrm{kW})\end{array}$ & $\begin{array}{c}\text { Fuel Consumed } \\
(\ell / \text { hour })\end{array}$ & $\begin{array}{c}\text { Fuel cost } \\
(\mathrm{US} \$ / \ell)\end{array}$ & $\begin{array}{c}\text { Monthly fuel cost } \\
\text { US } \$\end{array}$ \\
\hline Residential & 2.5 & 1.0 & 0.73 & 525.60 \\
Office & 3.1 & 2.14 & 0.73 & $1,124.78$ \\
B. Elevator & 25 & 7.6 & 0.702 & $3,841.34$ \\
\hline
\end{tabular}

Table 7. Conventional power grid equivalent operational costs. Source: authors.

\begin{tabular}{lccc}
\hline Application & $\begin{array}{c}\text { Load Profile Consumption Energy in } \\
\text { 24 hours }(\mathrm{kWh})\end{array}$ & $\begin{array}{c}\text { Cost of } \mathrm{kWh} \\
(\mathrm{US} \$ / \mathrm{kWh})\end{array}$ & $\begin{array}{c}\text { Total Monthly Operation- } \\
\text { al cost US } \$\end{array}$ \\
\hline Residential & 7.54 & 0.118 & 26.7 \\
Office & 23.7 & 0.167 & 118.7 \\
B. Elevator & 124.8 & 0.167 & 625.2 \\
\hline
\end{tabular}

Table 8. Comparison of monthly operational costs. Source: authors.

\begin{tabular}{lccc}
\hline Application & Fuel Cell US $\$$ & Diesel Generator US $\$$ & Conventional Power Grid US $\$$ \\
\hline Residential & $1,477.80$ & 540.2 & 26.7 \\
Office & $2,738.78$ & $1,140.38$ & 118.7 \\
B. Elevator & $2,257.62$ & $3,965.97$ & 625.2 \\
\hline
\end{tabular}

\subsection{Cost comparison between fuel cells and conventional energy sources}

Table 8 shows the comparison between the monthly operation costs of fuel cells, diesel generators and conventional grid.

Without any additional incentive, fuel cell costs are higher than diesel generators for residential and office applications. However, fuel cells are cheaper than diesel generators as backup for building elevators. This last condition is due to the large amount of fuel consumed by the diesel generator (7.6 l/hour) and the associated fuel cost. In all the three cases, the conventional grid is cheaper than the two backup generators.

On the other hand, comparing only the fuel consumption costs (Table 2 and Table 7 ), and the conventional power grid, it is observed a significant reduction of the costs provided by the hydrogen. This condition shows that hydrogen is a cheap energy vector in Colombia for electric generation, although the depreciation of Table 3 was not included, which also must be very much lower.

\section{IMPACT OF THE GOVERNMENT INCENTIVES IN COLOMBIA OVER ELECTRIC GENERATION WITH FUEL CELLS}

The Act 1715 of 2014 is a firm step made in Colombia to encourage the use of non-conventional energy sources. This Act is aimed at achieving a sustainable economic development, reducing the greenhouse gasses emissions and promoting an efficient energy management [21]. Moreover, the Tax Statute of Colombia 
establishes additional incentives for companies using non-pollutant energy sources. In the following, those incentives are described and analyzed.

Generating with non-conventional sources. This incentive is aimed to companies obligated to pay an income tax, which invest in non-conventional sources. The Act gives to those companies the right to reduce their income tax a $50 \%$ of the value of the investment during five years. However, this deduction must not be higher than the 50\% of the total income tax of the company [21].

Exclusion of VAT. The equipment, machinery and national or imported services for pre-investment, investment, production, and energy use, associated with nonconventional sources, are exempt from paying the Value Added Tax-VAT. Similarly, equipment for measuring and assessment of potential resources are VAT free [21].

Instruments for promoting renewable energies. This benefit is aimed to natural persons and companies that have new investments or new projects related with non-conventional energy sources. Those projects are exempt from paying customs tariffs for importing machinery, equipment, and materials devoted to preinvestment and investment in those sources [21].

Accelerated depreciation of assets. The energy generation using non-conventional sources gets the benefit of accelerated depreciation. This benefit can also be applied to the machinery, equipment and facilities to pre-investment, investment, and operation of the non-conventional energy sources. The annual depreciation rate will not be higher than $20 \%$ of a global annual rate [21].

All those benefits are aimed mainly for legal persons like companies or organiza- tions with investment capacity. The impact of incentives on generation with nonconventional sources and accelerated depreciation of assets is the income tax that those companies have to pay to the government, reducing it depending on the investment in non-conventional energy sources. In Colombia, the income tax rate is about $25 \%$. Those incentives, generation with non-conventional sources and accelerated depreciation of assets, are summarized in Eq. (5), where In stands for the total income of the company and IV represents the investment.

$$
\text { Income Tax }=(\operatorname{In}-(I v * 0.2)) * 0.25-(I v * 0.5)
$$

Finally, with those incentives the legal persons can deduct their investment from the taxes in two years.

Due to the incentives by the exclusion of VAT and the use of instruments for promoting renewable energies, the VAT, and the import tariff will be zero (US\$0), reducing the fuel cell costs. According to the results in Table 3 concerning the fuel cell total purchasing and import cost, and Eq. (1) was used for calculating those values, the impact of the Act 1715 in the fuel cell costs is reported in Table 9.

In average, the purchasing and importation costs for each case are reduced near to $17.4 \%$. Table 10 shows the re-calculated fuel cell operation costs under the Act 1715 .

The Colombian Tax Statute provides incentives in the Article 158-2, where legal entities that have made investments related to control and environmental improvement has the right of deducting the $100 \%$ of the invested value, from their income tax [22]. Therefore, a legal entity can deduct from their taxes, the cost of a fuel cell intended to replace diesel generators. Hence the only costs will be related to the monthly hydrogen consumption. 
Impact of government incentives in the profitability of green energy production using fuel cells in Colombia

\begin{tabular}{lcccc}
\multicolumn{5}{c}{ Table 9. Example of deduction VAT and tariff from fuel cell costs. Source: authors. } \\
\hline \multirow{2}{*}{ Manufacturer } & $\begin{array}{c}\text { Power } \\
(\mathrm{kW})\end{array}$ & $\begin{array}{c}\text { Total Cost P\&I before the } \\
\text { incentive US } \$\end{array}$ & $\begin{array}{c}\text { Total Cost P\&I after the } \\
\text { incentive US } \$\end{array}$ & $\begin{array}{c}\text { \% of } \\
\text { Saving }\end{array}$ \\
\hline ReliOn & 2.5 & 12,185 & 10,091 & 17.2 \\
Horizon & 3.0 & 14,906 & 12,325 & 17.3 \\
Hydrogenics & 33 & 26,417 & 21,776 & 17.6 \\
\hline
\end{tabular}

Table 10. Comparison of monthly operational costs including the incentives over fuel cells. Source: authors.

\begin{tabular}{lcccc}
\hline Application & $\begin{array}{c}\text { Fuel Cell costs be } \\
\text { fore incentives US } \$\end{array}$ & $\begin{array}{c}\text { Fuel Cell costs after } \\
\text { incentives US } \$\end{array}$ & $\begin{array}{c}\text { Diesel Generator } \\
\text { costs US } \$\end{array}$ & $\begin{array}{c}\text { Conventional Power } \\
\text { Grid costs US } \$\end{array}$ \\
\hline Residential & $1,477.80$ & $1,226.6$ & 540.2 & 26.7 \\
Office & $2,738.78$ & $2,274.2$ & $1,140.38$ & 118.7 \\
B. Elevator & $2,257.62$ & $1,923.5$ & $3,965.97$ & 625.2 \\
\hline
\end{tabular}

Table 11. Comparison of monthly operational costs after the tax statute incentive. Source: authors.

\begin{tabular}{lccc}
\hline Application & Fuel Cell US\$ & Diesel Generator US\$ & Conventional Power Grid US\$ \\
\hline Office & 55.7 & $1,140.38$ & 118.7 \\
B. Elevator & 355.6 & $3,965.97$ & 625.2 \\
\hline
\end{tabular}

Table 11 presents the comparison of the monthly costs of the three energy sources for the office and building elevator cases, according to the tax incentive defined by the Article 158-2.

Such results evidence that fuel cells are a profitable alternative for legal entities: pollutant and noisy diesel generators used in offices and elevators, which can be replaced with a significantly saving in the operational costs, with the advantage of contributing to a cleaner environment. In fact, fuel cell operation will be cheaper than grid energy; although, that case is out of the Article 158-2.

Since the previous tax incentive applies only to legal entities, residential applications are out of the scope of Article 158-2. So, the next section proposes a new incentive for this sector, based on an analysis of international subsidies and experiences.

\section{COMPARISON BETWEEN COLOMBIAN GOVERNMENT INCENTIVES AND INTERNATIONAL SUBSIDIES}

There are many kinds of incentives around the world to minimize the cost of fuel cells either for stationary or mobile applications. For stationary applications, United States offers the Federal fuel cell tax incentives approved under The Emergency Economic Stabilization Act of 2008, which gives an investment tax credit of $30 \%$ of the fuel cell cost or US $\$ 3,000 / \mathrm{kW}$, whichever is less [23]. Moreover, it provides a residential energy-efficiency credit for fuel cells in joint occupancy houses up to US $\$ 3,334 / \mathrm{kW}$ [23]. Germany provides incentives to invest in fuel-cell-based $\mathrm{co}^{-}$ generation plants [24]. These incentives are intended for commercial enterprises and regional authorities aimed at supplying industrial plants or residential properties with an electrical capacity up to $20 \mathrm{~kW}$ [25], [26]. Each installation receives a fix amount of $€ 1,600$ per unit and an additional incentive depending on the performance, as reported in Table 12 [27].

Table 12. Funding amount by performance related component. Source: authors.

\begin{tabular}{ccc}
\hline $\begin{array}{c}\text { Min. Power } \\
(\mathrm{kW})\end{array}$ & $\begin{array}{c}\text { Max. Power } \\
(\mathrm{kW})\end{array}$ & $\begin{array}{c}\text { Incentive per } \\
\mathrm{kW} €\end{array}$ \\
\hline 0.25 & 1 & 8,000 \\
1 & 3 & 2,000 \\
3 & 5 & 1,000 \\
\hline
\end{tabular}


Impact of government incentives in the profitability of green energy production using fuel cells in Colombia

Table 13. U.S. Federal subsidies over fuel cell cost in Colombia. Source: authors.

\begin{tabular}{ccccc}
\hline $\begin{array}{c}\text { F.C. Power } \\
(\mathrm{kW})\end{array}$ & $\begin{array}{c}\text { Total Cost P\&I Fuel } \\
\text { Cells US } \$\end{array}$ & $\begin{array}{c}30 \% \text { of System } \\
\text { Price US } \$\end{array}$ & $\begin{array}{c}\text { US } \$ 3,000 \text { per } \\
\mathrm{kW}\end{array}$ & $\begin{array}{c}\text { Final cost after } \\
\text { subsidy }\end{array}$ \\
\hline 2.5 & 12,185 & 3,656 & 7,500 & 8,529 \\
3.0 & 14,906 & 4,472 & 9,000 & 10,434 \\
33 & 26,417 & 7,925 & 99,000 & 18,492 \\
\hline
\end{tabular}

Table 14. German subsidies over fuel cell costs in Colombia. Source: authors.

\begin{tabular}{cccc}
\hline $\begin{array}{c}\text { F.C. Power } \\
(\mathrm{kW})\end{array}$ & $\begin{array}{c}\text { Total Cost P\&I Fuel Cells } \\
\text { US } \$\end{array}$ & $\begin{array}{c}\text { Total incentive per kW } \\
€\end{array}$ & $\begin{array}{c}\text { Final cost after incentive } \\
\text { US } \$\end{array}$ \\
\hline 2.5 & 12,185 & 3,600 & 8,253 \\
3.0 & 14,906 & 3,600 & 10,974 \\
33 & 26,417 & 2,600 & 23,577 \\
\hline
\end{tabular}

Table 15. Japanese subsidies over fuel cell costs in Colombia. Source: authors.

\begin{tabular}{cccc}
\hline $\begin{array}{c}\text { F.C. Power } \\
(\mathrm{kW})\end{array}$ & $\begin{array}{c}\text { Total Cost P\&I Fuel Cells } \\
\text { US } \$\end{array}$ & $\begin{array}{c}\text { Total subsidy per fuel cell } \\
\text { US } \$\end{array}$ & $\begin{array}{c}\text { Final cost after subsidy } \\
\text { US } \$\end{array}$ \\
\hline 2.5 & 12,185 & 3,115 & 9,070 \\
3.0 & 14,906 & 3,115 & 11,791 \\
33 & 26,417 & 3,115 & 23,302 \\
\hline
\end{tabular}

Table 16. Comparison of monthly operational costs with the U.S. subsidies over the fuel cell costs in Colombia. Source: authors.

\begin{tabular}{ccccc} 
Application & $\begin{array}{c}\text { Fuel Cell costs } \\
\text { before incentives } \\
\text { US } \$\end{array}$ & $\begin{array}{c}\text { Fuel Cell costs after } \\
\text { U.S. Subsidies US } \$\end{array}$ & $\begin{array}{c}\text { Diesel Genera- } \\
\text { tor costs US } \$\end{array}$ & $\begin{array}{c}\text { Conventional Power } \\
\text { Grid costs US } \$\end{array}$ \\
\hline Residential & $1,477.80$ & $1,039.08$ & 540.2 & 26.7 \\
Office & $2,738.78$ & $1,933.82$ & $1,140.38$ & 118.7 \\
B. Elevator & $2,257.62$ & $1,687.02$ & $3,965.97$ & 625.2 \\
\hline
\end{tabular}

In Japan, the incentives are aimed to ENE-FARM units, which are fuel cells that extract hydrogen from LP gas to produce electricity in the range of $0.3-1 \mathrm{~kW}$ [28]. The ENE-FARM scheme started in 2009, and the Japan government gave a subsidy of US $\$ 14,987$ per unit to contribute to the purchase price. That subsidy was reduced to reach US $\$ 4,817$ in 2012 [29]. The current subsidy is about US\$3115 and it expires at the end of 2015 [30].

Comparing the costs of the fuel cells including by the Colombian incentives (Table 9) with the U.S., German and Japanese incentives presented in Tables $13-15$, it is evident that the last ones are stronger, particularly the U.S. incentives, which provide a larger reduction in the fuel cell costs.

Based on the incentives provided by the U.S., German and Japanese, a new incentive to promote residential fuel cell applications could be defined. For example, recalculating the fuel cell monthly operation costs, i.e. using Eq. (2), including the U.S. federal subsidies over the fuel cell cost reported in Table 13, enables to estimate the impact of such incentives scheme in 
the Colombian market as reported in Table 16.

Even in this new scenario, the fuel cells are still more expensive in comparison with diesel generators for residential applications.

Therefore, it is required an additional incentive of $48 \%$ over the fuel cell cost to become fuel cells competitive with diesel generators in residential applications. Although this fact probably requires a significant investment by the Colombian state, it would be a necessary incentive to develop a pilot plan to stimulate the adoption of fuel cells in urban and rural areas, which is aimed to reducing the pollution caused by fossil fuels. Such initiative will eventually improve the quality of life in the country.

Other mechanisms to promote the adoption of fuel cell usage within the $\mathrm{Co}^{-}$ lombian electric market would be establishing an Energy Standard Portfolio [31], in which the government subsidizes the energy providers with a specific fund [31] to decrease the high costs of the fuel cells. It is possible since the Act 1715 of 2014 created the fund named FENOGE (Fondo de Energias No Convencionales y Gestión Eficiente de la Energia in Spanish) to support programs or projects related to nonconventional energy. This fund is also a suitable option to develop fuel cell projects in a large scale, for the non-interconnected zones, aimed at gradually replacing the conventional diesel generators.

\section{CONCLUSIONS}

An analysis of the government incentives for profitable energy production using fuel cells in Colombia has been presented. The results show that fuel cells, without any additional incentive, are a profitable option to replace diesel generators as backup sources for building elevator applications.
Concerning the tax structure in Colombia, the present incentives in the Act 1715 of 2014 and the Tax Statute provide a good structure to encourage the use of fuel cells as backup sources for legal persons in urban areas to reducing the pollutant emissions.

The proposed additional subsidies over the fuel cell cost (48\%) will enable the use of those non-pollutant sources in residential applications. This new incentive could trigger a large scale migration from fossil fuel generators to cleaner alternatives to improve the quality of life in Colombian cities.

This analysis not considering opportunity cost, due that some factors are complex to quantify, for example, environmental benefits and those that change unpredictably in the time, such as fuel cost, subsidies, and regulations. Therefore, the operation cost is only considering the current cost of fuel and the depreciation cost.

\section{ACKNOWLEDGMENTS}

This paper was supported by Universidad Nacional de Colombia, COLCIENCIAS and Automatic, Electronic and Computer Science research group of the Instituto Tecnológico Metropolitano (ITM), under the projects FC121056236765, FC-SIM-26687 (Jóvenes Investigadores - 2014), P14215 and P14220.

\section{REFERENCIAS}

[1] F. A. Farret and M. G. Simões, "Power Plants with Fuel Cells," in Integration of Alternative Sources of Energy, Hoboken, NJ, USA: John Wiley $\{\&\}$ Sons, Inc., 2006, p. 408.

[2] D. Saheb-Koussa, M. Koussa, and N. Said, "A Technical, Economic, and Environmental Performance of GridConnected Hybrid (Photovoltaic- 
Wind) Power System in Algeria," Sci. World J., vol. 2013, pp. 1-12, 2013.

[3] S. Curtin and J. Gangi, "The Business Case for Fuel Cells 2014: Powering the Bottom Line for Businesses and Communities," Washington, D.C., 2014.

[4] Entergy Arkansas, "A Comparison: Land Use by Energy Source Nuclear, Wind and Solar," New Orleans; LA, USA.

[5] International Partnership for Hydrogen and Fuel Cells in the Economy, "Communiqué," 2009. [Online]. Available: http://www.iphe.net/docs/IPHE Communique Draft For December 2009 SC Clean - Final.pdf.

[6] Ley 26.123 Régimen para el desarrollo de la tecnología, producción, uso y aplicaciones del hidrógeno como combustible y vector energía. República Argentina, 2006.

[7] F. Aliaga, F. N. Pondal, and M. Laborde, "La Ley de Promoción del Hidrógeno en Argentina: con un Plan Nacional de Hidrógeno ya redactado y a la espera de la reglamentación," Revista Petroquímica. Petróleo, Gas, Química \& Energía. 2015.

[8] J. T. Pukrushpan, A. G. Stefanopoulou, and H. Peng, Control of Fuel Cell Power Systems: Principles, Modeling, Analysis and Feedback Design, Illustrate. London, UK: Springer Science $\{\&\}$ Business Media, 2013.

[9] Solaredge, "Single Phase Solar Inverters," 2015. [Online]. Available: http://www.solaredge.com/groups/inv erter/single-phase-solar-inverter. [Accessed: 05-Jun-2015].

[10] C. F. Morales-Sánchez, "Cálculo de una tarifa de alimentación para instalaciones fotovoltaicas residenciales en Colombia," Semest. Económico, vol. 16, no. 34, pp. 13-40,
2013.

[11] B. A. Thornton, M. I. Rosenberg, E. E. Richman, W. Wang, Y. Xie, J. Zhang, H. Cho, V. V Mendon, R. A. Athaye, and B. Liu, "Achieving the 30\% Goal: Energy and Cost Savings Analysis of ASHRAE Standard 90.12010," Richland, WA, 2011.

[12] Plug Power, "Gensure E-2500 Hydrogen Cell," Gensure: Predictable backup power for an unpredicrable world. Retrieved August 17, 2015, from

https://www.plugpower.com/products /gensure/e-2500/

[13] Horizon, "Horizon Fuel Cell Shop," Shop. Retrieved November 11, 2015, from http://www.horizonfuelcellshop.com/ americas/.

[14] HYDROG(E)NICS, "Contact," Sales. 2015. Retrieved October 25, 2015, from

http://www.hydrogenics.com/contact

[15] DHL International, "Intermediación aduanera, seguridad y seguro internacional," DHL Colombia -Logística. Retrieved January 25, 2016, from http://www.dhl.com.co/es/logistica/se guridad_y_seguro_aduanero.html.

[16] Cooldimes S.A.S., "Servicios Integrales de Intermediación Aduanera," Servicios. Retrieved January 22, 2016, from http://www.cooldimes.com/Servicios. html.

[17] Ministerio de Comercio Industria y Turismo, "Decreto 4589 de 2006: Por el cual se adopta el Arancel de Aduanas y otras disposiciones." p. 333, 2006.

[18] DIAN -- Dirección de Impuestos y Aduanas Nacionales, "Consulta Arancel," Servicios en Línea Muisca. Retrieved January 18, 2016, from https://muisca.dian.gov.co/WebAranc el/DefMenuConsultas.faces. 
[19] World Summit on Sustainable Development, "Plan of Implementation of the World Summit on Sustainable Development," Johannesburg, 2002.

[20] World Water Forum, The 3er World Water Forum: Final Report. Kyoto, Shiga $\{\&\}$ Osaka, Japan: Nexxus Communications K.K., 2003.

[21] LEY 1715 DE 2014:Por medio de la cual se regula la integración de las energias renovables no convencionales al Sistema Energético Nacional. República de Colombia, 2014, p. 26.

[22] Dirección General de Impuestos Nacionales, "Estatuto Tributario Nacional Art. 158-2. Deducción por inversiones en control $y$ mejoramiento del medio ambiente." Dirección General de Impuestos Nacionales, 1989.

[23] Office of Energy Efficiency \& Renewable Energy, "Financial Incentives for Hydrogen and Fuel Cell Projects," U.S. Department of Energy. 2008.

[24] Federal Ministry of Transport and Digital Infrastructure of Germany, "New Funding guideline: Fuel cells for highly efficient combined heat and power plants." [Online]. Available:

http://www.bmvi.de/SharedDocs/DE/ Artikel/G/foerderrichtlinie-

brennstoffzellen-fuer-kraft-waermekopplungsanlagen.html?nn=36210.

[25] M. Lang and A. Lang, "BMVI Investment Grants for Fuel Cell CHP Plants," Environmental Politics and Fuel Cells. 2015.

[26] Federal Ministry of Transport and Digital Infrastructure of Germany,
"Fuel Cells for highly efficient cogeneration systems - Fuel Cell CHP Directive." [Online]. Available: ttp://www.bmvi.de/SharedDocs/DE/A nlage/VerkehrUndMobilitaet/foerder richtlinie-brennstoffzellen-fuer-

kraft-waermekopplungsanlagen.pdf?_blob=public ationFile.

[27] Federal Ministry of Transport and Digital Infrastructure of Germany, "Call for Proposals in accordance with the funding guidelines - Fuel Cells for highly efficient combined heat and power plants." [Online]. Available:

http://www.bmvi.de/SharedDocs/DE/ Anlage/VerkehrUndMobilitaet/foerd errichtlinie-brennstoffzellen-fuerkraft-waerme-kopplungsanlagenaufruf-

antragseinreichung.pdf?_blob=publi cationFile.

[28] Japan LP Gas Association, "Homeuse Fuel Cell(ENE-FARM)," Appliances. 2015.

[29] D. Carter, "Analyst View - Latest Developments in the Ene-Farm Scheme," London, UK, 2013.

[30] International Partnership for Hydrogen and Fuel Cells in the Economy, "Overview of FC \& H2 Development in JAPAN," in 21st IPHE Educational Event, 2014, p. 16.

[31] Á. I. Cadena, S. Botero, C. Táutiva, L. Betancur, and D. Vesga, "Regulación para incentivar las energías alternas y la generación distribuida en Colombia' (Conclusiones)," Rev. Ing., no. 28, pp. 1-9, 2008. 